\title{
What determines the exit decision for leveraged buyouts? is
}

\author{
Tim Jenkinson ${ }^{\mathrm{a}, *}$, Miguel Sousa ${ }^{\mathrm{b}}$ \\ ${ }^{a}$ Saïd Business School, University of Oxford and CEPR, United Kingdom \\ ${ }^{\mathrm{b}}$ School of Economics and Management, University of Porto and CEF.UP, Portugal
}

\section{A R T I C L E I N F O}

\section{Article history:}

Received 7 March 2014

Accepted 11 June 2015

Available online 10 July 2015

\section{JEL classification:}

G11

G14

G24

Keywords:

Secondary buy-out

Exits

Private equity

\begin{abstract}
A B S T R A C T
How and when to exit portfolio company investments are critical choices facing private equity funds. In this paper we analyze 1022 European private equity exits, using information on fund and portfolio company characteristics, and on conditions in capital markets. For over $43 \%$ of the exits, private equity funds sold to each other and we analyze why such secondary buyouts have gained in popularity relative to IPOs and sales to corporate acquirers. We find that the exit route depends on various portfolio company characteristics, and that conditions in the debt and equity markets have a strong influence on exit choice. The existing literature has tended to portray the IPO is the "preferred" exit route. However, our analysis suggests this is mistaken: private equity funds take advantage of 'windows of opportunity', and the exit route that maximizes value varies with market conditions.
\end{abstract}

(ㄷ) 2015 Elsevier B.V. All rights reserved.

\section{Introduction}

Exiting portfolio company investments is one of the most critical choices faced by private equity funds. Yet little is known about the timing of exit decisions or the choice of the exit route - which are broadly IPO, sale to another company ("trade sale") or sale to another private equity fund ("secondary exit"). The aim of this paper is to fill this gap and provide insights into the timing of private equity exits, and the choices made by private equity firms.

Previous research has tended to focus on the IPO as an exit route (Lerner, 1994; Murray, 1994; Barry et al., 1990; Giot and Schwienbacher, 2007). However, IPOs are relatively uncommon, with the vast majority of private equity exits being trade or secondary sales. Furthermore, the recent growth of secondary buy-outs has generated considerable controversy. As we show, around $43 \%$ of all exits were secondary sales in recent years. Some commentators refer to these as "pass the parcel" deals, implying that the ultimate value of the company - once the music stops and the true value is revealed by a sale to someone other

\footnotetext{
We thank Ulf Axelson, Jack Edmondson, Bastian Hinterramskogler, Jose Martinez, Han Ozsoylev, Tarun Ramadorai, Oren Sussman, Dimitrios Tsomocos the participants in the 2010 PFN Conference and 2011 European Financial Management Conference, three anonymous referees, and the editor for useful comments and valuable suggestions. We also thank S\&P Capital IQ Leveraged Commentary and Data for providing us with information on leveraged loan spreads and leverage multiples. Miguel Sousa gratefully acknowledges financial support from the Fundação para a Ciência e a Tecnologia, Portugal.

* Corresponding author.
}

than another private equity fund - is very uncertain. Investors (the Limited Partners in the fund, or LPs) often complain about such deals. In particular, when an LP is an investor in both the selling and acquiring fund, they continue to hold a stake in the company, but have paid often significant transactions fees and, in some cases, will have crystalized a profit share (or "carried interest", which is typically $20 \%$ of the profits) for the exiting private equity manager (the General Partner, or GP).

Given the way private equity funds are incentivized, in particular the fact that they earn carried interest provided the fund beats a hurdle rate expressed in terms of the whole fund internal rate of return (IRR), the timing of the exit cannot be divorced from the route chosen. A rapid exit will boost the IRR, and so private equity funds will, to some extent, trade off the immediacy, and certainty, of an exit route with maximizing value. An important contribution of this paper is to analyze the time-to-exit dynamics, using a hazard function framework. Although much of the literature asserts that IPOs are associated with "successful" exits, they do not result in quick, or certain, proceeds for private equity funds, given the requirement for their stakes to be locked-up for at least 6 months, and the difficulty of disposing of significant stakes. ${ }^{1}$ Secondary sales are relatively quick, the proceeds are certain and, unlike trade

\footnotetext{
1 The financial performance of LBOs that return to public markets relative to conventional IPOs has been studied by Cao and Lerner (2009) and Cao (2011). The latter paper provides evidence that private equity funds sell-down their stakes in companies they take back to public markets surprisingly slowly. This confirms that an IPO is only, in itself, a partial exit, and the achievement of full exit can take several years in practice.
} 
sales where competitors often emerge as the most likely purchasers, they seldom involve regulatory issues. Consequently, secondary sales are often welcomed by LPs. The controversy regarding secondary transactions is, therefore, mainly focused on the purchasing GP. Why are they buying a company that has already been worked on actively by another GP for several years? ${ }^{2}$

To analyze these issues, the paper focuses on exits of European private equity leveraged buyouts (LBOs) between January 2000 and December 2014 using a very large (self-collected) sample of 1022 portfolio companies. ${ }^{3}$ Previous studies as Sudarsanam (2005) studied the exit choice for 104 UK LBOs investments and found that operating performance, firm size, length of holding period and whether the firm belonged to the 'high-tech' industry were all significant determinants of the exit strategy. Wang (2012) also studies UK secondary exits. As Wang only has data on a relatively small number of companies she does not differentiate between IPOs and trade sales as alternative exit routes. ${ }^{4}$ Using our much larger pan-European dataset we are able to identify the main factors that influence whether private equity funds choose to exit via IPO, trade sale, or a sale to another financial buyer. Cumming and MacIntosh (2003b), focus mainly on the determinants of a partial exit, as opposed to a full exit, within the full range of exit vehicles and found that the greater the degree of information asymmetry between the private equity firm and the buyer, the greater the likelihood of a partial exit and suggested that partial exits were used as a signal of a portfolio company's quality.

This paper considers three sets of factors - which are likely to interact - that could influence the timing of exit and the choice of exit route.

First, we investigate the impact of market conditions. Private equity firms want to achieve the best exit price possible and capital market conditions may create different 'windows of opportunity'. For instance, higher availability of funds in the loan market, a "cold" IPO market or large amounts of capital committed but not yet invested in the private equity industry may make secondary buy-outs the most profitable exit route. Consistent with this hypothesis, Axelson et al. (2013) find that a higher availability of debt (measured by leverage multiples - Total Debt/EBITDA ${ }^{5}$ - used in leverage buyouts) has a strong impact on the prices of deals as private equity firms borrow as much as they can for each deal. Shivdasani and Wang (2011) also document the important impact of credit markets and securitization, and show that the LBO boom in the years before the financial crisis was largely fuelled by cheap debt with few covenants. ${ }^{6}$ Therefore favorable debt market conditions may increase the likelihood of a secondary buy-out transaction.

On the equity side, the well-documented cycles in the number of initial public offerings (and in the initial returns of such IPOs) also suggest the existence of windows of opportunity in the public equity markets. ${ }^{7}$ For instance, whilst relatively few private equity exits to public markets were observed in the years following the financial crisis, there was a flurry of private equity-backed IPOs during 2014.

\footnotetext{
2 Achleitner and Figge (2014) and Bonini (2015) have analyzed the sources of value creation for secondary buyouts. Guo et al. (2011) and Harford and Kolasinski (2013) study value creation in buyouts more generally, irrespective of the chosen exit route. A summary of evidence regarding financial performance of buyouts in general can be found in Cumming et al. (2007).

${ }^{3}$ We focus on buyouts as entry and exit are much easier to observe compared with venture capital deals where there can be multiple rounds of investing and divesting.

${ }^{4}$ Wang (2012) only identifies 5 IPOs in her UK sample; we have 142 in our broader European sample.

${ }^{5}$ EBITDA - Earnings Before Interest, Taxes, Depreciation and Amortization.

${ }^{6}$ Also, as noted by Groh and Gottschalg (2011), buyout transactions tend to happen in lower risk industries, and so the availability of leverage becomes important to generate higher returns (even if not on a risk-adjusted basis).

7 See for instance Ibbotson and Jaffe (1975), Ritter (1984) and Lowry and Schwert (2002).
}

The second set of factors we consider relate to the private equity fund structure. As noted earlier, private equity investing is generally carried out through partnerships/funds that have a contractually finite life, normally ten years, which can be extended only with the consent of the LPs. Moreover, private equity firms set up new funds approximately every three to five years and a good track record for timely exits as well as past performance are crucial to enhancing a firm's reputation and future fundraising (Phalippou (2008)). Therefore, when a private equity fund is near the end of its contractual life, the GP faces pressure to realize investments. $^{8}$ Consistent with this observation, Masulis and Nahata (2009) found in the case of trade sales that the returns of the purchasing company are, on average, higher when the selling private equity fund is closer to maturity. Cumming and Macintosh (2003a) conjecture that as the fund approaches its maturity, there may be portfolio companies that are not yet ready for a public offering or a strategic sale, which may make a secondary sale attractive, insofar as it can avoid having to request an extension on the life fund.

More benignly, GPs have different specializations. Some are focused on earlier stages of investment and others on expansion or late-stage investments, and so the recent wave of secondary buy-outs may have occurred because portfolio companies matured and grew and so were sold to other private equity firms that focus on such companies. ${ }^{9}$ In this case we might expect the two private equity firms involved in a secondary transaction should differ in terms of their experience, specialization, etc. Therefore, these various characteristics such as the holding period of the investment, how close the fund is to maturity, and the experience or specialization of the private equity fund may influence exit choice.

The final set of factors we consider relate to the portfolio company. It may be that some companies are more suited to particular exit routes. For instance, companies which can operate with high levels of debt - due to stable cash-flows or low investment needs - may be particularly suitable for continued private equity ownership, and so more likely to realize a secondary exit. And, emphasizing the point that these sets of factors can interact, the probability of a secondary exit for such a company would be expected to increase further when debt market conditions are favorable. Or it could be that firms have different monitoring needs, as suggested by Bienz and Leite (2008). In their model highly profitable companies - which require less monitoring - are more likely to be exited through an IPO whereas less profitable companies are exited via a trade sale. We explore whether such firm characteristics can explain exit choices.

Our main results are as follows. First, our analysis suggests that capital market conditions are the most important determinant of the exit route. Private equity funds exploit the windows of opportunity that open at different times. For instance, in 2006-07 the extraordinary conditions in the credit market made possible the use of higher levels of debt in European buy-outs. Furthermore, the huge amount of capital that was committed to private equity before the financial crisis led to a shift in demand. Together these factors made private equity firms willing to pay more for portfolio companies, which increased their bargaining power relative to corporate acquirers, and resulted in a high proportion of secondary sales.

Second, we find an important role for portfolio company characteristics. In particular, as would be expected, secondary buy-outs are more likely when the portfolio company's characteristics

\footnotetext{
${ }^{8}$ Arcot et al. (2015) use an exit in year 9 or 10 of the life of the private equity fund as a sign that the GP is "under pressure".

9 "If you have different funds with different strategies, it's natural that firms will want to buy and sell to each other" says Ross Marshall of Dunedin Capital Partners in September 2001 and "[P]rivate equity bosses say secondary buy-outs can be a way to take a company to a new level" in Financial Times (4th November 2010).
} 
(higher cash flow and lower capital expenditures needs) make the company more able to bear significant amounts of debt in their capital structure.

Third, regarding fund characteristics we find evidence that experienced private equity firms tend to sell to the less experienced, and that that secondary deals tend to happen at a later point in the life of the purchasing fund than primary deals. This suggests that secondary purchases might be a quick way of using up committed capital towards the end of the fund investment period. We also find evidence that IPOs are used as an early exit route, which is consistent with the view that IPOs can be attractive as marketing devices for raising a subsequent fund. However, the data also suggests that, if private equity firms cannot perform a public offering within a short period after the initial investment, they may prefer to exit through a secondary buy-out to keep their investment periods short, so as to realize high IRRs and facilitate fundraising. These results suggest that exit choices are, to some extent, driven by the private equity firms' desire to raise their next fund, which may conflict with the interest of their investors.

The remainder of the paper is structured as follows. Section 2 explains how the sample is constructed, summarizes the data, and analyzes the time-to-exit decision using a survival analysis framework. A multivariate econometric model for exit route choice is presented in section 3. Section 4 compares the characteristics of the private equity firms that participate as vendors or purchasers in secondary buy-outs. Section 5 concludes.

\section{Data construction and sample characteristics}

\subsection{Sample construction}

One of the main issues concerning private equity research is the availability of data. Because private equity-backed companies are not publicly traded they do not have the same obligations regarding the disclosure of information as publicly traded companies. This is particularly problematic for U.S. companies (except those that have issued public bonds). However, European companies are still required to file accounting statements in the public domain. In this paper, therefore, we focus on European portfolio companies, as defined by the country of their headquarters; we make no restrictions on the country of origin of the private equity fund.

The dataset used in this paper is assembled from several sources and databases in a complex and multi-step process. ${ }^{10}$ The initial universe consists of all European private equity investments ${ }^{11}$ that exited through a public offering, a trade sale or a secondary buy-out between January 2000 and December $2014 .{ }^{12}$ We are limited in going back before 2000 as it is very difficult to get accounting statements before that date. We then restrict the sample to those investments where it is possible to (i) identify the private equity firm(s) and fund(s) involved, (ii) identify the entry deal (merger/acquisition or a private placement) date, and (iii) obtain accounting data for the year before the exit.

The first step in building the database is to identify private equity exits. For this two databases are used, S\&P Capital IQ and Private Equity Insight. These databases complement each other

\footnotetext{
10 A more detailed explanation of this process is available upon request.

11 The definition of private equity investments, in the study, excludes venture capital investments.

12 Liquidations were dropped because, in order to exclude venture capital investments the sample only includes exits with transaction (exit) value higher than $\$ 50 \mathrm{~m}$ $(£ 25 \mathrm{~m}$ ) and the low (or even zero) value of a liquidation would mean that none of these transactions would have made the cut off. Buy-backs were dropped because they either are used as a subsequent exit (after an initial public offering) or in small, venture capital type investments. And finally, dividend recapitalizations were dropped because they are not an exit per se, but combine a cash distribution with balance sheet restructuring.
}

and so combining them provides a broad and representative sample of private equity exits. Using these databases, it is possible to identify 1023 secondary buy-outs, 1231 trade sales and 313 initial public offerings, in a total of 2567 private equity exits, occurring between January 2000 and December 2014.

The second step involves gathering detailed transaction/exit data. Thomson Venture Expert (TVE) and S\&P Capital IQ are used to identify the selling private equity firms and funds involved in each transaction and their characteristics, such as the year the private equity was founded, the fund vintage year and the fund size. When more than one private equity firm is identified in the same transaction, if one of the private equity firms led the transaction (retained a higher percentage of shares on the deal) only the information about the leader and their fund is used. If none of the private equity firms receive more shares than the other(s) or no information about that aspect is available, information on all private equity firms and funds data is obtained and the data on firm and fund characteristics is averaged.

S\&P Capital IQ, TVE and Zephyr ${ }^{13}$ are used to obtain information about the entry deal date. Accounting data is collected from FAME, AMADEUS and ORBIS, ${ }^{14}$ and occasionally from S\&P Capital IQ. Only the deals for which accounting data regarding the portfolio company is available for at least the year before the exit are retained. Information about the portfolio company's founding year is collected from S\&P Capital IQ TVE or the Internet.

From the 2567 private equity exits identified in the first step we are able to collect the data required for 446 secondary buy-outs, 434 trade sales (to either publicly-listed or private companies) and 142 public offerings, producing a total of 1022 private equity exits. Fig. 1 shows the exit route distribution by year. These exits represent our sample for the remainder of the paper. Table 1 reports the nationality (Panel A) and the industry (Panel B) of the sample portfolio companies and Table 2 shows the (selling) private equity firms involved. 28 European countries and more than 300 private equity firms are represented in this sample, with the UK accounting for almost one-half of the portfolio companies. We believe this to be the most comprehensive sample of European private equity exits yet collected.

Information about the local stock market return index is collected from the relevant stock exchange websites. Capital committed to private equity funds and not yet invested is obtained from Preqin. Finally, three different measures of debt market conditions are collected. The FED tightening Index ${ }^{15}$ is collected from the Board of Governors of the Federal Reserve System website and represents the net percentage of domestic banks that have tightened standards for Commercial and Industrial (C\&I) Loans in a quarter. Finally, monthly interest margins on leveraged loans and leverage multiples in European buy-outs are obtained from S\&P Capital IQ's Leveraged Commentary and Data (LCD).

\subsection{Summary statistics}

Table 3 provides summary information for the 1022 deals. The average holding period of all deals is just over 4 years. This is slightly longer than the 3.7 years found by Schwienbacher (2008a) and in the middle of the 3-5 year interval suggested by Fenn et al. (1997). On average, private equity funds make their investments about two years into the life of the fund (25.0 months) and exit their investments after around six years (76.2 months). Not surprisingly, holding periods increased noticeably after the

\footnotetext{
13 Zephyr contains information on deals, such as merger and acquisitions and IPOs. 14 FAME, AMADEUS and ORBIS contain information on public and private companies for the UK \& Ireland, Europe and the rest of the world (respectively). FAME, AMADEUS, ORBIS and Zephyr are managed by Bureau van Dijk.

15 Senior Loan Officer Opinion Survey on Bank Lending Practices. For more information on this survey, see www.federalreserve.gov/boarddocs/snloansurvey.
} 


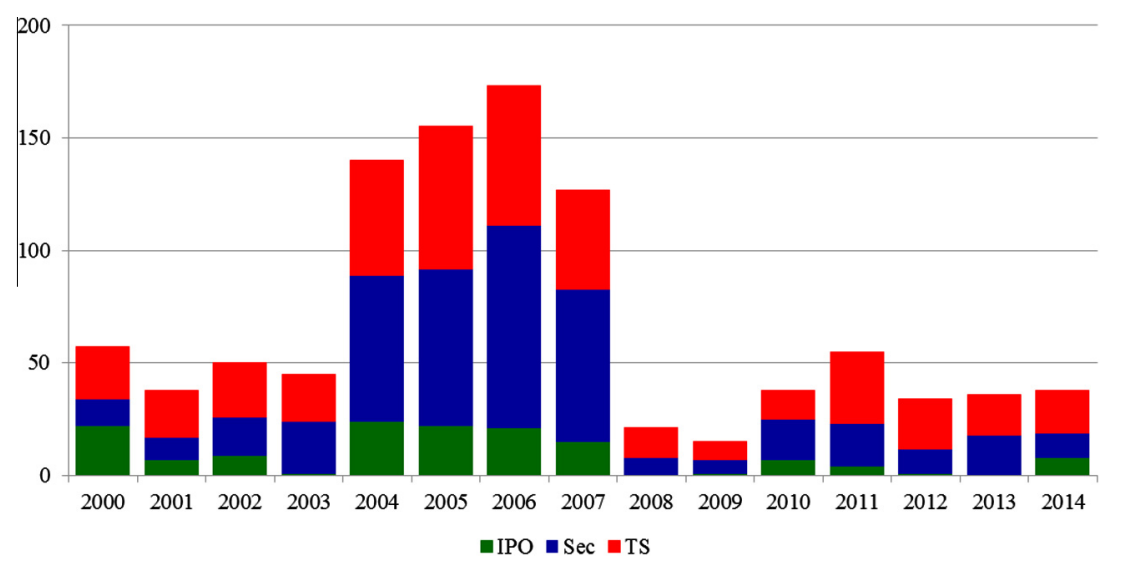

Fig. 1. Exits distribution by route and year. This figure shows our sample of 1022 private equity exits by route and year.

Table 1

Sample description. This table gives details about the 1022 exits of European companies, which occurred between January 2000 and December 2014. Panel A sorts the sample by portfolio company nationality (according to the location of their headquarters) and according to whether their exit route was an initial public offering (IPO), secondary sale to another private equity fund ( $\mathrm{Sec}$ ) or a trade sale to a corporate acquirer (TS). Nationality means the country where the portfolio company has its headquarters. Panel B sorts the sample by broad industrial classification and by exit route.

\begin{tabular}{|c|c|c|c|c|c|}
\hline \multirow[t]{2}{*}{ Country } & \multicolumn{5}{|l|}{ Exit route } \\
\hline & IPO & \multicolumn{2}{|l|}{ Sec } & TS & Total \\
\hline \multicolumn{6}{|c|}{ Panel A: Nationality of portfolio companies and exit routes } \\
\hline United Kingdom & 64 & 198 & \multicolumn{2}{|r|}{182} & 444 \\
\hline France & 13 & 84 & \multicolumn{2}{|r|}{53} & 150 \\
\hline Sweden & 11 & 23 & \multicolumn{2}{|r|}{36} & 70 \\
\hline Germany & 12 & 28 & \multicolumn{2}{|r|}{27} & 67 \\
\hline Italy & 4 & 34 & \multicolumn{2}{|r|}{27} & 65 \\
\hline Spain & 3 & 14 & \multicolumn{2}{|r|}{19} & 36 \\
\hline Netherlands & 3 & 15 & \multicolumn{2}{|r|}{16} & 34 \\
\hline Norway & 8 & 13 & \multicolumn{2}{|r|}{12} & 33 \\
\hline Finland & 2 & 8 & \multicolumn{2}{|r|}{16} & 26 \\
\hline Denmark & 2 & 10 & \multicolumn{2}{|r|}{7} & 19 \\
\hline Belgium & 2 & 5 & \multicolumn{2}{|r|}{8} & 15 \\
\hline Ireland & 5 & 1 & \multicolumn{2}{|r|}{4} & 10 \\
\hline Austria & 4 & 2 & \multicolumn{2}{|r|}{2} & 8 \\
\hline Other 15 & 9 & 11 & \multicolumn{2}{|r|}{25} & 45 \\
\hline Industry & & IPO & Sec & TS & Total \\
\hline \multicolumn{6}{|c|}{ Panel B: Industrial classification of portfolio companies } \\
\hline \multicolumn{2}{|c|}{ Agriculture and Mining } & 4 & 6 & 12 & 22 \\
\hline \multicolumn{2}{|c|}{ Construction } & 2 & 8 & 9 & 19 \\
\hline \multicolumn{2}{|c|}{ Manufacturing } & 55 & 182 & 178 & 415 \\
\hline \multicolumn{2}{|c|}{ Transportation and Communication } & 10 & 33 & 51 & 94 \\
\hline \multicolumn{2}{|c|}{ Retail and Wholesale Trade } & 22 & 67 & 47 & 136 \\
\hline \multicolumn{2}{|c|}{ Financial and Other services } & 49 & 150 & 137 & 336 \\
\hline
\end{tabular}

2008 financial crisis. The average (median) fund size is $\$ 938$ million (\$456 million) while the private equity firms have on average, at the time of the exit, around 20 years of experience. ${ }^{16}$

Regarding the target portfolio companies, in the year before the exit they have average (median) book assets of $\$ 328$ million ( $\$ 97$ million), sales of $\$ 320$ million (\$109 million) and EBIT of $\$ 25$ million ( $\$ 9.3$ million).

In Table 4 we differentiate between exit routes. Panel A shows that investments exited through a secondary buy-out are held for an average (median) of 52.7 months (49.5 months), compared with 51.8 months (48.5) and 44.7 months (42.2) for trade sales and IPOs respectively. The holding period differences between the

\footnotetext{
${ }^{16}$ If the private equity firm was founded before 1970 , we use 1970 as the founding year, as little activity existed in the European private equity industry before that date.
}

Table 2

Sample description: Exits by selling private equity firm. This table reports the selling private equity firm and exit routes used in the 1022 exits of European companies which occurred between January 2000 and December 2014. If more than one private equity firm was involved and none was the leader (got a higher percentage of shares on the deal) all private equity firms were considered.

\begin{tabular}{lllll}
\hline \multirow{2}{*}{ Private equity firm } & \multicolumn{2}{l}{ Exit route } & & \\
\cline { 2 - 5 } & IPO & Sec & TS & Total \\
\hline 3i Group & 15 & 34 & 41 & 90 \\
Bridgepoint Capital & 2 & 20 & 18 & 40 \\
Apax Partners & 11 & 11 & 15 & 37 \\
Barclays Private Equity & 1 & 18 & 8 & 27 \\
EQT Partners & 9 & 9 & 9 & 27 \\
CVC Capital Partners & 6 & 9 & 9 & 24 \\
Cinven & 3 & 10 & 8 & 21 \\
Industri Kapital & 2 & 9 & 9 & 20 \\
Nordic Capital & 4 & 7 & 8 & 19 \\
Carlyle Group & 3 & 9 & 7 & 19 \\
Candover Investments & 2 & 8 & 7 & 17 \\
Permira & 3 & 9 & 5 & 17 \\
Other 297 & 87 & 340 & 317 & 744 \\
\hline
\end{tabular}

Table 3

Summary Statistics for the entire sample. This table reports the summary statistics for deal holding period, characteristics of private equity investors and funds involved, target portfolio company's age, size and operating performance, at the time of exit, for 1022 deals exited between January 2000 and December 2014 (dollars in millions).

\begin{tabular}{lllll}
\hline Variables & Average & Median & Std. deviation & $N$ \\
\hline $\begin{array}{l}\text { Panel A: Deal and PE investor } \\
\text { Holding period (months) }\end{array}$ & 51.2 & 48.1 & 25.8 & 1022 \\
$\begin{array}{l}\text { Fund maturity (months) } \\
\text { Fund size }\end{array}$ & 76.2 & 72.9 & 31.5 & 979 \\
PE age at exit (years) & $\$ 938.0$ & $\$ 455.7$ & $\$ 1,360.4$ & 981 \\
Panel B: Portfolio company & 20.3 & 20.0 & 9.7 & 1022 \\
Age at exit (years) & & & & \\
Total assets & 37.8 & 21.5 & 41.6 & 1022 \\
Turnover & $\$ 328.0$ & $\$ 97.4$ & $\$ 846.5$ & 1022 \\
EBIT & $\$ 320.2$ & $\$ 108.7$ & $\$ 819.1$ & 1019 \\
EBIT margin & $\$ 25.5$ & $\$ 9.3$ & $\$ 81.7$ & 1022 \\
Asset turnover ratio & $8.94 \%$ & $13.29 \%$ & $12.33 \%$ & 1017 \\
CAPEX & 1.51 & 1.23 & 1.29 & 1019 \\
CAPEX/Total assets & $\$ 23.4$ & $\$ 5.1$ & $\$ 151.2$ & 942 \\
& $9.48 \%$ & $6.92 \%$ & $12.01 \%$ & 941 \\
\hline
\end{tabular}

sub-sample of deals exited through an IPO and the sub-sample of deals exited through a secondary buyout are statistically significant at the $1 \%$ level. Panel A also reports the maturity of the private equity fund at the point of exit. Secondary buy-outs are exited later in the fund life (78 months) than investments exited through a trade sale (76.5 months) or through an IPO (70 months). The difference between IPOs and secondary buy-outs is statistically 
Table 4

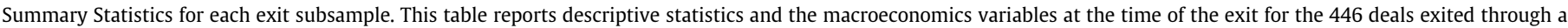

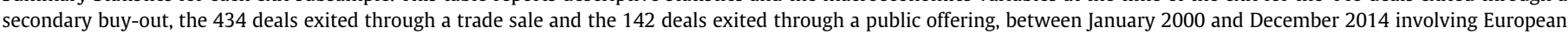

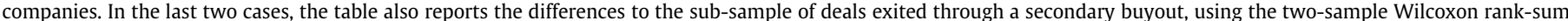

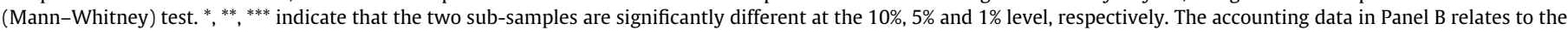
last full-year accounts prior to the exit. All reported dollar values are in millions.

\begin{tabular}{|c|c|c|c|c|c|c|c|c|}
\hline \multirow[t]{2}{*}{ Variables } & \multicolumn{2}{|c|}{ Secondary buy-out } & \multicolumn{3}{|c|}{ Trade sale } & \multicolumn{3}{|l|}{ IPO } \\
\hline & Average & Median & Average & Median & $z$ & Average & Median & $z$ \\
\hline \multicolumn{9}{|l|}{ Panel A: Deal and PE investor } \\
\hline Holding period (months) & 52.7 & 49.5 & 51.8 & 48.5 & -1.16 & 44.7 & 42.2 & $-3.82^{* * *}$ \\
\hline Fund maturity (months) & 78.1 & 74.2 & 76.5 & 72.7 & -1.10 & 69.8 & 68.2 & $-2.73^{* * *}$ \\
\hline Fund size & $\$ 920.0$ & $\$ 458.7$ & $\$ 880.8$ & $\$ 416.0$ & -1.21 & $\$ 1,168.5$ & $\$ 608.0$ & $2.09^{* *}$ \\
\hline PE age at exit (years) & 20.0 & 20.0 & 20.6 & 20.0 & 0.76 & 20.2 & 20.0 & 0.15 \\
\hline \multicolumn{9}{|l|}{ Panel B: Portfolio company } \\
\hline Age at exit (years) & 40.2 & 25.0 & 34.7 & 18.0 & $-3.05^{* * *}$ & 39.6 & 17.5 & $-1.70^{*}$ \\
\hline Total assets & $\$ 290.4$ & $\$ 113.0$ & $\$ 262.7$ & $\$ 72.2$ & $-4.42^{* * *}$ & $\$ 645.9$ & $\$ 122.3$ & -0.42 \\
\hline Turnover & $\$ 292.7$ & $\$ 135.6$ & $\$ 263.8$ & $\$ 81.9$ & $-4.79^{* * *}$ & $\$ 582.1$ & $\$ 149.8$ & -0.37 \\
\hline EBIT & $\$ 24.3$ & $\$ 12.5$ & $\$ 18.4$ & $\$ 6.5$ & $-6.10^{* * *}$ & $\$ 51.1$ & $\$ 9.4$ & -1.52 \\
\hline EBIT margin & $10.7 \%$ & $14.2 \%$ & $8.3 \%$ & $12.7 \%$ & $-2.88^{* * *}$ & $5.4 \%$ & $12.4 \%$ & $-3.53^{* * *}$ \\
\hline Asset turnover ratio & 1.5 & 1.2 & 1.6 & 1.3 & 0.77 & 1.4 & 1.1 & -1.48 \\
\hline CAPEX & $\$ 20.6$ & $\$ 5.9$ & $\$ 18.5$ & $\$ 3.8$ & $-2.62^{* * *}$ & $\$ 48.0$ & $\$ 11.9$ & $2.41^{* * *}$ \\
\hline CAPEX/Total assets & $8.5 \%$ & $6.0 \%$ & $8.6 \%$ & $6.9 \%$ & 0.20 & $15.4 \%$ & $11.6 \%$ & $4.83^{* * *}$ \\
\hline \multicolumn{9}{|l|}{ Panel C: Macroeconomics } \\
\hline Local stock market return & $2.5 \%$ & $3.3 \%$ & $2.2 \%$ & $2.8 \%$ & -0.89 & $4.5 \%$ & $3.7 \%$ & $1.67^{*}$ \\
\hline Capital commitment index return & $3.1 \%$ & $4.0 \%$ & $2.5 \%$ & $2.7 \%$ & $-2.74^{* * *}$ & $2.6 \%$ & $3.0 \%$ & $-2.20^{* *}$ \\
\hline Margins on BB loans & 2.36p.p. & 2.03p.p. & 2.55p.p. & 2.31p.p. & $4.03^{* * *}$ & 2.47p.p. & 2.27p.p. & $2.16^{* *}$ \\
\hline Fed tightening index & $-4.5 \%$ & $-8.8 \%$ & $-1.4 \%$ & $-8.8 \%$ & 1.10 & $1.0 \%$ & $-8.8 \%$ & $1.93^{*}$ \\
\hline Leverage multiple & 5.01 & 4.98 & 4.92 & 4.79 & $-2.27^{* *}$ & 4.88 & 4.82 & $-2.39^{* *}$ \\
\hline
\end{tabular}

Table 5

Exit distribution along the private equity fund life. This table reports the distribution of the different exits (secondary buy-out, trade sale and public offering) along the fund's life.

\begin{tabular}{llll}
\hline \multirow{2}{*}{ Years since the vintage year } & Exit & & \\
\cline { 2 - 4 } & Secondary buy-out & Trade sale & IPO \\
\hline $1-2$ & 0.04 & 0.05 & 0.08 \\
$3-4$ & 0.19 & 0.20 & 0.25 \\
$5-6$ & 0.34 & 0.34 & 0.31 \\
$7-8$ & 0.25 & 0.22 & 0.26 \\
$9-10$ & 0.12 & 0.11 & 0.07 \\
+10 & 0.06 & 0.07 & 0.03 \\
\hline
\end{tabular}

significant. IPOs tend to be used more by larger funds (more than $\$ 1$ billion), but the experience of private equity firms is not related to the choice of exit route.

Table 4 Panel B provides summary information on specific characteristics of portfolio companies. Companies that exit through a secondary buy-out are significantly older ( 40.2 years) than those using a trade sale (34.7 years) or an IPO (39.6 years). Consistent with the finding of Sudarsanam (2005), companies using secondary exits are, in the year before the exit, also more profitable - having an average (median) EBIT margin (EBIT/Turnover) equal to $10.7 \%$ (14.2\%). By contrast, those portfolio companies that exit through an IPO tend to be larger, to invest the highest proportion of total assets (15.4\%) and have the lowest profitability in terms of EBIT margin.

These results suggest that exit via a secondary buy-out is more likely to be used for mature portfolio companies with higher capacity to generate cash-flow and earnings (to support significant levels of debt) and for companies that require less investment.

Axelson et al. (2013) show that the macro economy is an important determinant of exit route. We summarize macroeconomic conditions at the time of exit in Table 4 Panel C. IPOs tend to be used after periods of strong returns: markets increase, on average, by $4.5 \%$ during the $3-6$ month period before the public offering. ${ }^{17}$

\footnotetext{
17 All macroeconomics variables are recorded in the quarter before the exit because such decisions are made some time before the transaction closes.
}

This is consistent with the existence of IPO windows of opportunity when shareholders take advantage of "hot" IPO markets. Secondary buy-outs are most frequent during periods when private equity fund have raised (but not yet spent) large amounts of capital, and when credit is cheap and lending conditions are loose. This tends to suggest the existence of secondary buy-out 'windows of opportunity' during which the secondary exit route leads to higher returns.

Table 5 summarizes how exit routes vary over the fund life. Masulis and Nahata (2009) conclude that private equity investors face a liquidity pressure as their funds approach maturity. In our sample $64 \%$ of IPO exits happen during the first six years of a fund, $26 \%$ during the seventh and eighth years, and only $10 \%$ happen after the eight year. In the case of secondary buyouts and trade sales, the majority of exits also happen between the fifth and the eighth years of the fund's life, but $6 \%$ occur after the tenth year.

\subsection{Hazard functions}

In order to understand exit dynamics during the life of the fund, we next analyze the time-to-exit using a survival analysis framework, similar to that employed by Giot and Schwienbacher (2007). ${ }^{18}$ The hazard function gives the conditional instantaneous probability of exit given that the deal has not been exited at that specific time (the hazard rate) ${ }^{19}$

$\lambda(t)=\lim _{\Delta t \rightarrow 0}\left(\frac{\operatorname{Pr}(t \leqslant T<t+\Delta t \mid T \geqslant t)}{\Delta t}\right)=\frac{f(t)}{S(t)}=-\frac{S^{\prime}(t)}{S(t)}$

Where

$S(t)=\operatorname{Pr}(T>t)=1-\mathrm{F}(\mathrm{t})$ (survivor function)

$F(t)=\operatorname{Pr}(T \leqslant t)$ (exit time distribution function)

$f(t)=\mathrm{d} F(t) / \mathrm{d} t$ (density function of exit time distribution)

\footnotetext{
18 Contrary to their model, the holding period variable is not right-censored since all deals have been exited at the time of data collection. For more detail on survival analysis and/or hazard models see Giot and Schwienbacher (2007) and Cameron and Trivedi (2005).

19 Also called the intensity function, the conditional failure rate or the inverse Mills ratio, "is the instantaneous rate of failure" (Cleves et al., 2010).
} 


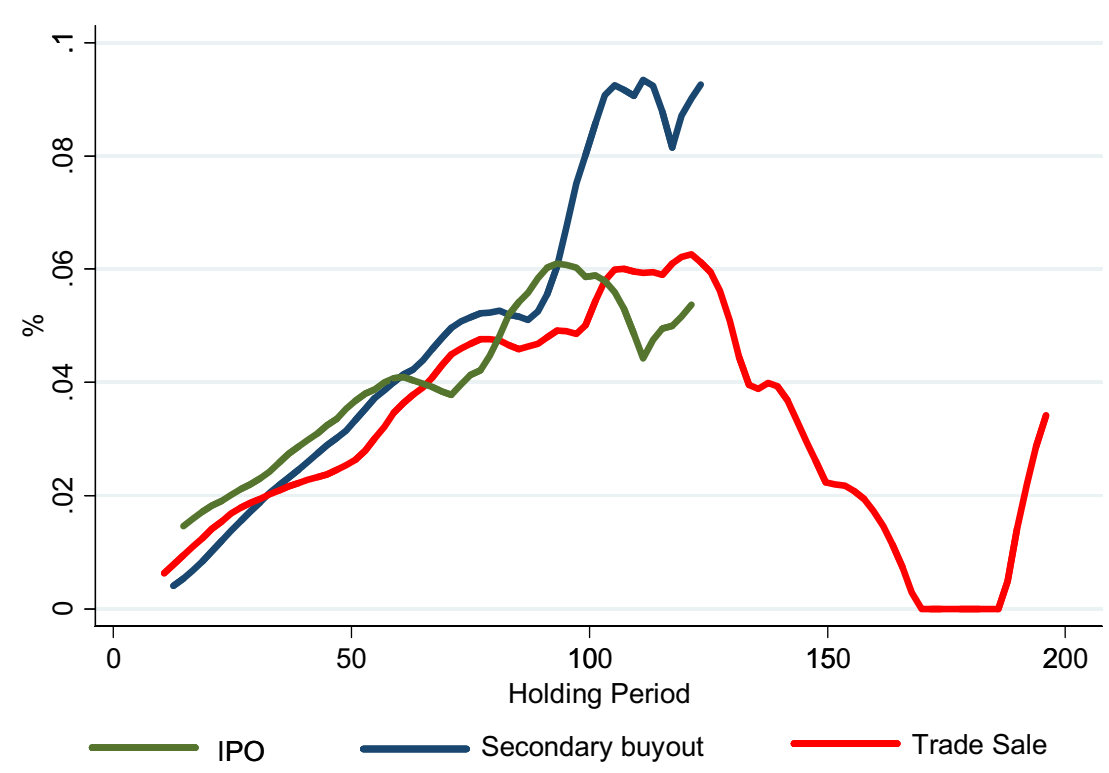

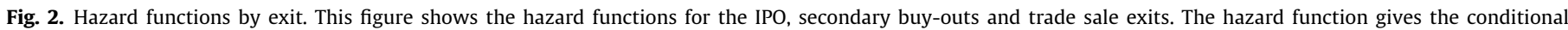
instantaneous probability of exit given that the deal has not been exited at that specific time.

Table 6

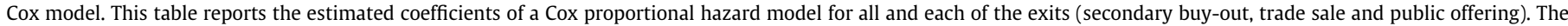

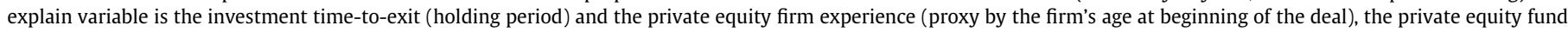

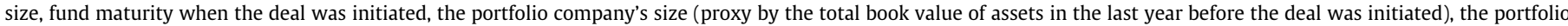

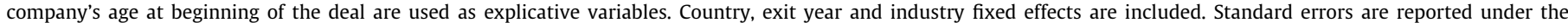
coefficients in parenthesis and ${ }^{*},{ }^{* *},{ }^{* * *}$ indicate levels that are significantly different from zero at the $10 \%, 5 \%$ and $1 \%$, respectively.

\begin{tabular}{|c|c|c|c|c|}
\hline \multirow[t]{2}{*}{ Variables } & \multicolumn{4}{|l|}{ Exit } \\
\hline & All & Secondary buy-out & Trade sale & IPO \\
\hline ln (PE firm age at entry) & $\begin{array}{l}-0.058 \\
(0.048)\end{array}$ & $\begin{array}{c}-0.077 \\
(0.073)\end{array}$ & $\begin{array}{l}0.000 \\
(0.088)\end{array}$ & $\begin{array}{l}-0.146 \\
(0.184)\end{array}$ \\
\hline In (fund maturity at entry) & $\begin{array}{l}0.172^{* * *} \\
(0.038)\end{array}$ & $\begin{array}{l}0.141^{* *} \\
(0.061)\end{array}$ & $\begin{array}{l}0.164^{* * *} \\
(0.059)\end{array}$ & $\begin{array}{l}0.544^{* * *} \\
(0.167)\end{array}$ \\
\hline $\ln$ (fund size) & $\begin{array}{l}0.143^{* * *} \\
(0.033)\end{array}$ & $\begin{array}{l}0.094^{*} \\
(0.049)\end{array}$ & $\begin{array}{l}0.193^{* *} \\
(0.055)\end{array}$ & $\begin{array}{l}0.351^{* *} \\
(0.144)\end{array}$ \\
\hline In (portfolio company age at entry) & $\begin{array}{l}0.054^{* *} \\
(0.024)\end{array}$ & $\begin{array}{l}0.071^{*} \\
(0.039)\end{array}$ & $\begin{array}{c}-0.027 \\
(0.041)\end{array}$ & $\begin{array}{l}0.204^{* *} \\
(0.082)\end{array}$ \\
\hline In (portfolio company total assets) & $\begin{array}{l}-0.071^{* * *} \\
(0.026)\end{array}$ & $\begin{array}{c}-0.022 \\
(0.043)\end{array}$ & $\begin{array}{l}-0.106^{* *} \\
(0.046)\end{array}$ & $\begin{array}{c}-0.178^{* *} \\
(0.073)\end{array}$ \\
\hline Country and exit year fixed effects & Included & Included & Included & Included \\
\hline Industry fixed effects & Included & Included & Included & Included \\
\hline Observations & 882 & 386 & 369 & 127 \\
\hline LR Chi ${ }^{2}$ & $150.45^{* * *}$ & $55.26^{*}$ & $82.44^{* * *}$ & $105.95^{* *}$ \\
\hline
\end{tabular}

"Other sectors" is the base industry dummy.

The hazard functions for each exit route are shown in Fig. 2, and provide some interesting evidence on the dynamics of the exit process. First, the exit probabilities are broadly similar for the first 90 months of the fund, although trade sales are generally less likely during this initial period. Second, thereafter the probability of conducting an IPO drops off sharply, with secondary buyouts becoming by far the most likely exit route. Third, as funds head towards final liquidation, the remaining companies are sold to trade purchasers, with no instances of IPOs or secondary sales after the 10 -year point.

The survival analysis can be extended using a Cox proportional hazard model ${ }^{20}$ where hazard rates depend on a set of covariates that can be viewed as explanatory variables:

\footnotetext{
20 This model is a semi-parametric model that makes no assumptions about the form of the baseline hazard function, $\lambda_{0}(t)$, which does not have to be specified. This fact makes the Cox model considerably flexible and widely used.
}

$\lambda(t)=\lambda_{0}(t) \cdot e^{\left(\beta_{0}+\beta_{1} \cdot X_{1}+\beta_{2} \cdot X_{2}+\ldots+\beta_{k} \cdot X_{k}\right)}$

The explanatory variables we include are the private equity firm experience, the fund size and maturity when the deal was initiated, the portfolio company's size (proxied by the total book value of assets), and the portfolio company's age at beginning of the deal. Industry, exit year and country fixed effect are also included.

The estimation results are shown in Table 6. The model shows as expected, given the limited life of a fund - that investments initiated later in the life of the fund take less time to be exited. Larger funds tend to exit their investments more quickly. Regarding portfolio company characteristics, older companies tend to be exited more quickly, and larger portfolio companies exited more slowly. We find no evidence that the experience of the GP has a significant effect on the speed of exit.

This section has looked in detail at the timing of the exit decision, for each exit route. In the next section we switch focus to the exit decision itself. 
Table 7

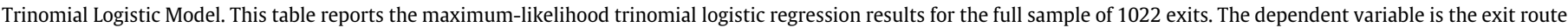

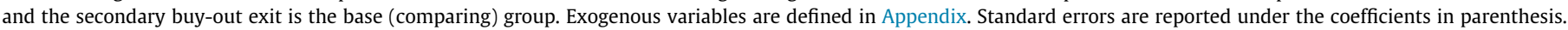
${ }^{*},{ }^{* *},{ }^{* *}$ indicate significance level at $10 \%, 5 \%$ and $1 \%$, respectively. ' + ' indicates a winsorized variable at 0.05 and 0.95 percentiles.

\begin{tabular}{|c|c|c|c|c|c|c|c|c|c|}
\hline \multirow[t]{2}{*}{ Variables } & & \multicolumn{2}{|l|}{ Model 1} & \multicolumn{2}{|l|}{ Model 2} & \multicolumn{2}{|l|}{ Model 3} & \multicolumn{2}{|l|}{ Model 4} \\
\hline & & TS & IPO & TS & IPO & TS & IPO & TS & IPO \\
\hline Deal an PE variables & $\begin{array}{l}\ln \text { (fund maturity) } \\
\ln \text { (fund size) } \\
\ln \text { (pe age) }\end{array}$ & $\begin{array}{l}-0.353^{* *} \\
(0.165) \\
-0.140^{* *} \\
(0.058) \\
0.371^{* * *} \\
(0.141)\end{array}$ & $\begin{array}{l}-0.538^{* *} \\
(0.228) \\
0.124 \\
(0.087) \\
-0.032 \\
(0.198)\end{array}$ & & & & & $\begin{array}{l}0.039 \\
(0.182) \\
-0.011 \\
(0.065) \\
0.227 \\
(0.147)\end{array}$ & $\begin{array}{l}-0.017 \\
(0.273) \\
0.277^{* * *} \\
(0.103) \\
0.010 \\
(0.224)\end{array}$ \\
\hline PC variables & $\begin{array}{l}\text { In (pc age) } \\
\text { ln (total assets) } \\
\text { EBIT margin }^{+} \\
\text {Asset turnover ratio } \\
\text { CAPEX/Total Assets } \\
\text { Turnover growth }\end{array}$ & & & $\begin{array}{l}-0.112 \\
(0.079) \\
-0.166^{* * *} \\
(0.057) \\
-0.019^{* * *} \\
(0.007) \\
-0.034 \\
(0.091) \\
-0.004 \\
(0.007) \\
0.004 \\
(0.003)\end{array}$ & $\begin{array}{l}-0.018 \\
(0.118) \\
0.022 \\
(0.081) \\
-0.033^{* * *} \\
(0.009) \\
-0.090 \\
(0.134) \\
0.038^{* * *} \\
(0.009) \\
0.007^{* *} \\
(0.003)\end{array}$ & & & $\begin{array}{l}-0.081 \\
(0.080) \\
-0.148^{* *} \\
(0.060) \\
-0.021^{* * *} \\
(0.007) \\
-0.016 \\
(0.092) \\
-0.005 \\
(0.007) \\
0.005^{*} \\
(0.003)\end{array}$ & $\begin{array}{l}-0.030 \\
(0.117) \\
-0.022 \\
(0.085) \\
-0.033^{* * *} \\
(0.010) \\
-0.026 \\
(0.133) \\
0.035^{* * *} \\
(0.010) \\
0.009^{* * *} \\
(0.004)\end{array}$ \\
\hline Macroeconomics var. & $\begin{array}{l}\text { Local stock index return } \\
\text { Capital commitment index return } \\
\text { Fed Tightening Index } \\
\text { Country fixed effects } \\
\text { Industry fixed effects }\end{array}$ & $\begin{array}{l}\text { Included } \\
\text { Included }\end{array}$ & & $\begin{array}{l}\text { Included } \\
\text { Included }\end{array}$ & & $\begin{array}{l}0.008 \\
(0.010) \\
-0.086^{* * *} \\
(0.031) \\
0.004 \\
(0.004) \\
\text { Not included } \\
\text { Included }\end{array}$ & $\begin{array}{l}0.055^{* * *} \\
(0.014) \\
-0.093^{* *} \\
(0.045) \\
0.012^{* *} \\
(0.005)\end{array}$ & $\begin{array}{l}0.009 \\
(0.011) \\
-0.102^{* * *} \\
(0.034) \\
0.003 \\
(0.004) \\
\text { Not included } \\
\text { Included }\end{array}$ & $\begin{array}{l}0.049^{* * *} \\
(0.016) \\
-0.089^{*} \\
(0.050) \\
0.013^{* *} \\
(0.006)\end{array}$ \\
\hline $\begin{array}{l}\text { Observations } \\
\text { LR Chi }\end{array}$ & & $\begin{array}{l}972 \\
193.25^{* * *}\end{array}$ & & $\begin{array}{l}936 \\
224.96^{* * *}\end{array}$ & & $\begin{array}{l}1008 \\
184.16^{* * *}\end{array}$ & & $\begin{array}{l}876 \\
205.8^{* * *}\end{array}$ & \\
\hline
\end{tabular}

\section{Regression results}

We hypothesize that the choice of exit route depends on three groups of factors relating to the investor, the portfolio company and the market environment. In this section we use a discrete choice Trinomial Logistic Model to analyze the exit route decision.

\subsection{Trinomial Logistic Model and variables}

The exit route probability model is based on a trinomial logistic regression using the exit routes as the dependent variable, which assumes the value 0 if the exit route is a secondary buy-out, 1 if it is a trade sale, and 2 if it is an IPO. Deal and private equity investor characteristics (x), portfolio company characteristics $(\mathbf{w})$ and macroeconomic environment factors $(\mathbf{z})$ are used as independent variables to explain the choice of exit route:

$\mathrm{y}_{\mathrm{i}}=\mathbf{x}_{\mathrm{i}}^{\prime} \boldsymbol{\beta}_{\mathrm{i}}+\mathbf{w}_{\mathrm{i}}^{\prime} \boldsymbol{\lambda}_{\mathrm{i}}+\mathbf{z}_{\mathrm{i}}^{\prime} \boldsymbol{\delta}_{\mathrm{i}}+\mathrm{u}_{\mathrm{i}}$

The $\mathbf{x}$ variables include the fund maturity, represented by the number of months (at exit) since the vintage year ${ }^{21}$, the fund size, and the age of the private equity firm at the exit date. The $\mathbf{w}$ variables include company size (represented by total assets), company age, the EBIT margin (as a measure of profitability), the turnover-assets ratio (as a measure of capital intensity), the CAPEX-assets ratio (as a measure of investment intensity), and the growth rate of turnover. All these accounting variables are measured in the last year before the exit.

Previous work has suggested how these variables may impact on the exit decision. Pagano et al. (1998) show that the "larger companies are more likely to go public", mostly because they face less direct (administrative) and indirect (underpricing) costs. Gompers (1995), Cumming and Macintosh (2003a) and

\footnotetext{
21 As the exact date of the fund close is unknown, we use July 1 for all funds. Detailed descriptions of all variables and definitions are presented in the Appendix.
}

Schwienbacher (2008b) have shown that, due to fixed costs, only companies above a threshold dimension should be expected to be exiting through a public offering. Ritter (1991) found a significant inverse relationship between underpricing and the age of the company in a public offering, which is consistent with Chemmanur and Fulghieri (1999) who showed that, in equilibrium, firms go public only when a sufficient amount of information about them has accumulated in the public domain.

Finally, regarding the macroeconomic environment at the time of the exit $(\mathbf{z})$, the return on the local stock market index ${ }^{22}$ is included as a proxy for the state of the IPO market. The Fed tightening index is used as proxy for the availability of capital in the credit market. Finally, the amount of capital available to private equity investors, sometimes referred to as "dry-powder", is included to proxy the competitive state of the private equity market.

Dummies variables that control for industry fixed effects and country fixed effects (in the models without macro country-level variables) are also included. The existence of outliers made some distributions relatively skewed and could lead to a distortion of statistical tests. As a result some variables are measured in natural logarithms or are winsorized. ${ }^{23}$

\subsection{Empirical results}

Table 7 shows the results for the trinomial model. The secondary buy-out exit is the comparison class. Separate equations

\footnotetext{
22 Although, it is possible for a portfolio company to be floated on overseas stock exchanges, the local stock exchange is normally the first choice because it is where potential investors have more information about the company and so it is easier to market the initial public offering.

${ }^{23}$ Logs were used for fund maturity, fund size, private equity firm age, portfolio company age and total assets. Winsorization (at the $5 \%$ and $95 \%$ points) was used only for variables expressed in percentage points, such as EBIT margin, asset turnover ratio, CAPEX over total assets, and turnover growth.
} 
Table 8

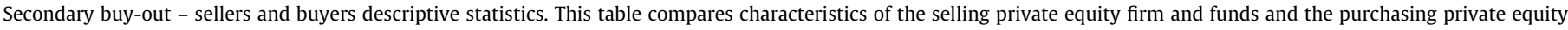

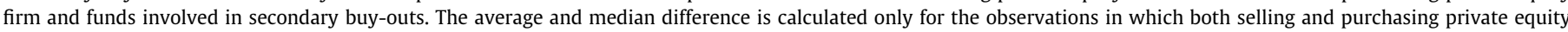

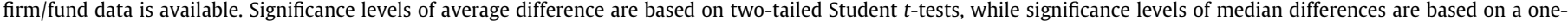
sample Wilcoxon sign-rank tests. *, **, *** indicate levels that are significantly different from zero at the $10 \%, 5 \%$ and $1 \%$, respectively.

\begin{tabular}{|c|c|c|c|c|c|c|c|c|c|}
\hline \multirow[t]{2}{*}{ Variables } & \multicolumn{3}{|c|}{ Selling PE } & \multicolumn{3}{|c|}{ Purchasing PE } & \multicolumn{3}{|c|}{ Difference } \\
\hline & $N$ & Average & Median & $N$ & Average & Median & $N$ & Average & Median \\
\hline \multicolumn{10}{|l|}{ Panel A: Private Equity Firm } \\
\hline PE age at exit/entry (years) & 446 & 20.0 & 20.0 & 438 & 18.7 & 19.0 & 438 & $1.3^{* *}$ & $2.0^{* *}$ \\
\hline Total funds & 404 & 12.6 & 7 & 391 & 11.0 & 6 & 356 & $1.6^{*}$ & 1.0 \\
\hline BO funds & 403 & 6.4 & 5 & 368 & 5.4 & 4 & 356 & $1.2^{* * *}$ & $1.0^{* * *}$ \\
\hline Total amount & 404 & $\$ 8,003$ & $\$ 2,838$ & 391 & $\$ 7,986$ & $\$ 2,134$ & 332 & $-\$ 227$ & $\$ 5$ \\
\hline Total BO funds amount & 403 & $\$ 5,603$ & $\$ 2,127$ & 387 & $\$ 5,262$ & $\$ 1,066$ & 352 & $\$ 268$ & $\$ 179^{*}$ \\
\hline \multicolumn{10}{|l|}{ Panel B: Private Equity Fund } \\
\hline Fund maturity at entry (months) & 420 & 25.7 & 22.3 & 295 & 31.9 & 26.9 & 274 & $-6.5^{* * *}$ & $-9.1^{* * *}$ \\
\hline Fund size & 425 & $\$ 920$ & $\$ 459$ & 277 & $\$ 1,735$ & $\$ 696$ & 261 & $-\$ 1,001^{* * *}$ & $-\$ 311^{* * *}$ \\
\hline
\end{tabular}

relate the probability of a trade sale to the probability of a secondary buy-out and the probability of an IPO to the probability of a secondary buy-out. ${ }^{24}$ Industry fixed effects are included in each model, and country fixed effects are included in Models 1 and 2, in which macroeconomic variables do not appear.

We start by including each set of explanatory variables separately. These models (1-3) suggest that trade sales are more likely to be used (relative to secondary sales) by more experienced private equity firms, by smaller funds, at an earlier stage in the fund life, and for smaller portfolio companies with lower margins. ${ }^{25}$ The probability of an IPO is higher earlier in the life of the fund, and for portfolio companies with higher CAPEX intensity and turnover growth. We also find that the probability of an IPO decreases with portfolio company profitability (as measured by EBIT margins), which contradicts the 'monitoring hypothesis'. These results suggest that the attractiveness of a secondary sale increases for companies with high margins and lower capital requirements - both of which would support the higher debt levels that would be used by secondary buyers.

Macroeconomic conditions are also found to be significant: the probability of choosing an IPO, over a secondary sale, is higher when the stock market has been increasing, when credit conditions have been getting tighter and when capital committed to private equity decreases. ${ }^{26}$ Secondary sales are more likely to be chosen over trade sales when capital committed to private equity is higher, as would be expected.

\footnotetext{
24 Although the exact value of the coefficient associated with any variable cannot be directly interpreted, a positive coefficient in the first (second) equation means that as the independent (exogenous) variable increases the ratio "probability of a trade sale (public offering)/probability of a secondary buy-out" increase, i.e., the probability of a trade sale (public offering) increases related with the probability of a secondary buy-out. By contrast, a negative coefficient associated to any variable means that the probability of a secondary buy-out related to the probability of a trade sale (public offering) increases as the independent (exogenous) variable increases.

${ }^{25}$ One additional year of experience of the private equity firm (around the mean of 20.3 years) increases the ratio "probability of a trade sale / probability of a secondary buy-out" by around $1.84 \%$. An increase of private equity fund size by $\$ 1$ million (around the mean of $\$ 938$ million) decreases the ratio "probability of a trade sale /probability of a secondary buy-out" by around $0.015 \%$. To exit the investment one month later in the fund life (around the mean of 76.2 months) decreases the ratio "probability of a trade sale /probability of a secondary buy-out" by around $0.46 \%$. An increase of portfolio company EBIT margin by 1 percentage point decreases the ratio "probability of a trade sale/probability of a secondary buy-out" by around $1.88 \%$.

26 A stock market return higher in 1 percentage point increases the ratio "probability of a public offering/probability of a secondary buy-out" by around $5.65 \%$. An increase of the net number of commercial banks tightening standards for corporate loans higher in 1 percentage points increases the ratio "probability of a public offering / probability of a secondary buy-out" by around $1.20 \%$. An increase of the capital commitment to private equity higher in 1 percentage point decreases the ratio "probability of a public offering / probability of a secondary buy-out" by around $8.89 \%$.
}

The three sets of explanatory variables are combined in Model 4 , and most of the conclusions of the earlier models are confirmed. The main difference is that the fund characteristics generally become less significant. On the other hand, controlling for the portfolio company and macroeconomic variables increases the significance of fund size for the choice between IPOs and secondary sales: larger funds are more likely to choose IPOs.

In summary, our results suggest that market conditions, which provide various windows of opportunity for GPs, are consistently important across all the specifications. Loosening credit conditions increase the probability of secondary sales, and periods of strong stock market performance and smaller commitments to private equity increase the probability of IPOs. Such effects are particularly pronounced for portfolio companies with a high debt capacity. Axelson et al. (2013) found such macroeconomic factors were critical determinants of the pricing and capital structure of LBOs; our results show that they also have a significant impact on the way deals are exited.

\section{Selling versus purchasing private equity firm and fund characteristics}

To this point we have focused on the exit choice for all LBOs in our sample. However, in this section we focus on the secondary buyouts and compare the characteristics of the selling and buying private equity firms, and the point the primary and secondary transactions took place in the life of the purchasing fund. For both the selling and purchasing private equity firms we gather data from Thomson One on firm age, the total number of private equity funds set up and the total amount raised, up to the date of each transaction. We further distinguish between private equity funds in general (including venture capital) and buyout funds.

Table 8, Panel A compares the private equity firms on each side of the secondary transactions. The results show that the selling private equity firm is, on average, 1.3 years older than the purchasing firm, and this difference is significant at the $5 \%$ level. In terms of fund formation, the selling firm had set up an average of 12.6 private equity funds -1.6 more than the purchasing firm. Focusing only on the buyout funds the difference is slightly higher and statistically significant. Regarding the amounts raised, the total for all fund types is very similar. There is, nonetheless, some evidence that selling private equity firms tend to be somewhat more experienced than purchasing firms.

We also consider, in Table 8 Panel B, whether sellers and purchasers differ in terms of the point in the fund life at which they buy the given firms. We find that the initial purchases occur, on average, two years after the vintage year. Interestingly, the secondary purchases happen, on average, significantly later at two and a half year after the vintage year. We also compare the size 
of the selling and purchasing funds. Purchasing funds are significantly larger than selling funds. However, to some extent this simply reflects the fact that capital committed to the private equity sector and buyout fund sizes were steadily increasing over our sample period.

This comparison of the parties involved in secondary transactions provides some evidence that, across our sample of deals, the experienced private equity firms tend to sell to the less experienced. The previous section provides little evidence to support the view that secondary transactions are more likely for those companies that have grown rapidly and could benefit from a new private equity owner to take them to the next level. If anything, the faster growing companies tended to exit to trade sales and IPOs. Therefore, the choice of secondary exit seems to be driven more by the fund characteristic than portfolio company factors. The fact that secondary deals tend to happen at a later point in the life of the purchasing fund than primary deals is intriguing. Most private equity funds claim that they focus mainly on primary deals, and our findings are consistent with funds turning to secondary transactions when they are unable to source sufficient primary deals. This would suggest, in general, that secondary buyouts should under-perform primary transactions. Although returns are not the focus of this paper, Degeorge et al. (2015) confirm this conjecture. They analyze the performance of secondary buyouts and find that, on average, they under-perform relative to primary deals. This is mainly driven by deals that occur later in the life of the purchasing fund - which they describe as "going for broke".

\section{Conclusions}

Using a new and comprehensive dataset consisting of all European companies exited by private equity firms between January 2000 and December 2014, this paper analyzes the determinants of exit timing and the exit route. We pay particular attention to the factors that might explain the growth of secondary transactions between private equity funds, which comprise $43 \%$ of the exits in our sample.

We find evidence that the choice between IPOs and secondary buyouts depends heavily on the conditions in the debt and equity market. When stock markets have been rising strongly, the use of IPOs, relative to secondary sales, increases. When debt is abundant and cheap, and when private equity firms have a lot of committed capital to deploy, we observe an increase in secondary buyouts. Furthermore, these effects are more pronounced for portfolio companies with a higher capacity to service debt - for instance, companies with higher levels of cash-flow and profitability, and with lower capital expenditure requirements. The choice between secondary buyouts and trade sales is influenced more by portfolio company characteristics, with trade sales being more likely for smaller companies that have experienced stronger growth.

The academic literature has tended to view IPOs as the "successful" exit route, but our results question whether such status is warranted. In contrast, many people view secondary buyouts with suspicion, but from the perspective of the selling private equity funds - and their investors - secondary buyouts have many attractions. The price is arrived at through an auction involving multiple potential purchasers. At closing the purchaser pays the full price, and the selling fund knows exactly what returns will be achieved. Investors receive their money back quickly thereafter. Therefore, to some extent, private equity firms provide liquidity to each other via secondary sales.

Contrast this process with the uncertainties of an IPO. At the start of the IPO process an investment bank gives an indication as to the likely price, but there is uncertainty about the outcome until the day before the bookbuilding closes. Often there are last-minute changes in the issue price, as the investment bank juggles the interests of the vendor and its buy-side clients. This inherent conflict of interest may go some way to explain the systemic underpricing of IPOs (see, for instance, Jenkinson and Jones (2009)), which GPs very much view as 'carried interest left on the table'. At the IPO, the private equity owner is only able to sell a proportion of their holding, and is subject to a lengthy lock-up on the remainder. Selling down the remaining (often large) stakes can take long periods of time. Therefore, proceeds are highly uncertain and investors do not obtain their money for many months or years after the IPO. From the perspective of the GP and their investors, an IPO is not an exit per se; it is a route to an exit.

Therefore, secondary sales have strong attractions from the viewpoint of the selling private equity funds. However, a rather different case needs to be made to justify secondary purchases. When we compare the characteristics of the private equity firms involved on both sides of secondary transactions, we find that the more experienced private equity firms tend to sell to the less experienced. We also find that secondary deals tend to happen at a later point in the life of the purchasing fund than the primary deals. This suggests that funds may tend to buy in secondary transactions when they cannot source good primary deals. This is consistent with the finding of Degeorge et al. (2015) that secondary deals bought later in the life of a fund tend to underperform.

In conclusion, our results provide support for the "window of opportunity' hypothesis, and reinforce the recent work by Axelson et al. (2013) who find similarly strong effects of market conditions on capital structure and pricing of leveraged buyouts. While the use of secondary buyouts varies with capital market conditions, and according to the portfolio and fund characteristics we identify, we expect them to continue to be one of the most commonly observed exit routes in the future. Private equity funds are highly incentivized to sell their portfolio companies for the highest price, with the lowest risk, and with the shortest delay in receiving the proceeds. Selling to another private equity fund often achieves these goals.

\section{Appendix. Variables}

\begin{tabular}{|c|c|}
\hline Variable & Definition \\
\hline $\begin{array}{l}\text { Holding period } \\
\text { (months) }\end{array}$ & $($ exit day - entry day)/30 \\
\hline Fund maturity (months) & $\begin{array}{l}{[(\text { day } 1 / \text { exit month/exit }} \\
\text { year })-(\text { day } 1 / \text { month } 7 / \text { vintage } \\
\text { year })] / 30\end{array}$ \\
\hline Fund size $(\$ \mathrm{~m})$ & Closed fund size \\
\hline $\begin{array}{l}\text { Private equity firm age } \\
\text { at exit (seller) (years) }\end{array}$ & $\begin{array}{l}\text { (exit year - pe firm founding } \\
\text { year }+1 \text { ) }\end{array}$ \\
\hline $\begin{array}{l}\text { Portfolio company age } \\
\text { at exit (years) }\end{array}$ & (exit year - pc founding year +1 ) \\
\hline Turnover $(\$ \mathrm{~m})$ & $\begin{array}{l}\text { (total sales value in the last profit } \\
\text { and loss statement before the exit } \\
\text { date) } \times 12 /(\text { number of months in } \\
\text { the statement) [annual equivalent] }\end{array}$ \\
\hline Total assets $(\$ \mathrm{~m})$ & $\begin{array}{l}\text { Total assets value in the last } \\
\text { accounting statement before the } \\
\text { exit date }\end{array}$ \\
\hline EBIT $(\$ m)$ & $\begin{array}{l}\text { (total EBIT value in the last profit } \\
\text { and loss statement before the exit } \\
\text { date) } \times 12 / \text { (number of months in } \\
\text { the statement) [annual equivalent] }\end{array}$ \\
\hline EBIT margin $(\times 100)$ & $\begin{array}{l}\text { (annual equivalent EBIT)/Total } \\
\text { sales } \times 100\end{array}$ \\
\hline
\end{tabular}

(continued on next page) 
Appendix (continued)

\begin{tabular}{|c|c|}
\hline Variable & Definition \\
\hline CAPEX $(\$ m)$ & $\begin{array}{l}\text { Total fixed assets value in the last } \\
\text { accounting statement before the } \\
\text { exit date - total fixed assets value } \\
\text { in the second from the last } \\
\text { accounting statement before the } \\
\text { exit date + depreciation and } \\
\text { amortizations value in the last } \\
\text { profit and loss statement before the } \\
\text { exit date }\end{array}$ \\
\hline $\begin{array}{l}\text { CAPEX/Total Assets } \\
\qquad(\times 100)\end{array}$ & CAPEX/Total Assets $\times 100$ \\
\hline $\begin{array}{l}\text { Local stock market } \\
\text { return }(\times 100)\end{array}$ & $\begin{array}{l}\text { Local index stock exchange } \\
\text { return } \times 100 \text { between six and three } \\
\text { months before the exit }\end{array}$ \\
\hline $\begin{array}{l}\text { Capital commitment } \\
\text { index return }(\times 100)\end{array}$ & $\begin{array}{l}\text { Preqin capital commitment index } \\
\text { return } \times 100 \text { in the quarter before } \\
\text { the exit }\end{array}$ \\
\hline Margins on BB loans & $\begin{array}{l}\text { "drawn margins on leveraged } \\
\text { institutional term loans BB" in the } \\
\text { quarter before the exit }\end{array}$ \\
\hline Fed index & $\begin{array}{l}\text { 'net percentage of domestic } \\
\text { respondents tightening standards } \\
\text { for C\&I Loans' } \times 100 \text { in the quarter } \\
\text { before the exit }\end{array}$ \\
\hline Leverage multiple & $\begin{array}{l}\text { Leverage multiple in the 3rd month } \\
\text { before the exit }\end{array}$ \\
\hline
\end{tabular}

Note: All values originally not in USD converted at historical exchange rate.

\section{References}

Achleitner, A.-K., Figge, C., 2014. Private equity lemons? Evidence on value creation in secondary buyouts. European Financial Management 20 (2), 406-433.

Arcot, S., Fluck, Z., Gaspar, J., Hege, U., 2015. Fund managers under pressure: Rationale and determinants of secondary buyouts. Journal of Financial Economics 115 (1), 102-135.

Axelson, U., Jenkinson, T., Strömberg, P., Weisbach, M.S., 2013. Borrow cheap, buy high? The determinants of leverage and pricing in buyouts. Journal of Finance 68 (6), 2223-2267.

Barry, C., Muscarella, C., Peavy, J., Vetsuypens, M., 1990. The role of venture capital in the creation of public companies: Evidence from the going-public process. Journal of Financial Economics 27 (2), 447-471.

Bienz, C., Leite, T., 2008. A Pecking Order of Venture Capital Exits. Working paper, Norwegian School of Economics and Business Administration.

Bonini, S., 2015. Secondary buyouts: operating performance and investment determinants. Financial Management 44 (2), 431-470.

Cameron, C., Trivedi, P., 2005. Microeconometrics - Methods and Applications. Cambridge University Press, Cambridge.
Cao, J.X., 2011. IPO timing, buyout sponsors' exit strategies, and firm performance of RLBOs. Journal of Financial and Quantitative Analysis 46 (4), 1001-1024.

Cao, J.X., Lerner, J., 2009. The performance of reverse leveraged buyout. Journal of Financial Economics 91 (2), 139-157.

Chemmanur, T.J., Fulghieri, P., 1999. A theory of the going-public decision. Review of Financial Studies 12 (2), 249-279.

Cleves, M., Gould, W., Gutierrez, R., 2010. An Introduction to Suvival Analysis using Stata, third ed. Stata Press, College Station, Texas.

Cumming, D., Siegel, D., Wright, M., 2007. Private equity, leveraged buyouts and governance. Journal of Corporate Finance 13 (4), 439-460.

Cumming, D., MacIntosh, J., 2003a. Venture-capital exits in Canada and the United States. The University of Toronto Law Journal 53 (2), 101-199.

Cumming, D., MacIntosh, J., 2003b. A cross-country comparison of full and partial venture capital exits. Journal of Banking and Finance 27 (3), 511-548.

Degeorge, F., Martin, J., Phalippou, L., 2015. On Secondary Buyouts. Journal of Financial Economics (forthcoming).

Fenn, G., Liang, N., Prowse, S., 1997. The Economics of the Private Equity Market. Staff Study no. 168, Board of Governors of the Federal Reserve System.

Giot, P. Schwienbacher, A., 2007. IPOs, trade sales and liquidations: Modelling venture capital exits using survival analysis. Journal of Banking and Finance 31 (3), 679-702

Gompers, P.A., 1995. Optimal investment, monitoring, and the staging of venture capital. The Journal of Finance 50 (5), 1461-1489.

Groh, A., Gottschalg, O., 2011. The effect of leverage on the cost of capital of US buyouts. Journal of Banking and Finance 35 (8), 2099-2110.

Guo, S., Hotchkiss, E., Song, W., 2011. Do buyouts (still) create value? Journal of Finance 66 (2), 479-517.

Harford, J., Kolasinski, A., 2013. Do private equity returns result from wealth transfers and short-termism? Evidence from a comprehensive sample of large buyouts. Management Science 60 (4), 888-902.

Ibbotson, R.G., Jaffe, J.F., 1975. 'Hot issue' markets. Journal of Finance 30 (4), 1027 1042 .

Jenkinson, T., Jones, H., 2009. IPO pricing and allocation: A survey of the views of institutional investors. Review of Financial Studies 22 (4), 1477-1504.

Lerner, J., 1994. Venture capitalists and the decision to go public. Journal of Financial Economics 35 (3), 293-316.

Lowry, M., Schwert, G., 2002. IPO market cycles: Bubbles or sequential learning? The Journal of Finance 57 (3), 1171-1200.

Masulis, R.W., Nahata, R., 2009. Venture capital conflicts of interest: Evidence from acquisitions of venture backed firms. Journal of Financial and Quantitative Analysis 46 (2), 395-430.

Murray, G., 1994. The second equity gap: Exit problems for seed and early stage venture capitalists and their investee companies. International Small Business Journal 12 (4), 59-76.

Pagano, M., Panetta, F., Zingales, L., 1998. Why do companies go public? An empirical analysis. The Journal of Finance 53 (1), 27-64.

Phalippou, L., 2008. The hazards of using IRR to measure performance. The case of private equity. Journal of Performance Measurement 12 (4), 55-66.

Ritter, J., 1984. The 'Hot issue' Market of 1980. Journal of Business 57 (2), 215-240.

Ritter, J., 1991. The long-run performance of initial public offerings. The Journal of Finance 46 (1), 3-27.

Schwienbacher, A., 2008a. Venture capital investment practices in Europe and the United States. Financial Markets and Portfolio Management 22, 195-217.

Schwienbacher, A., 2008b. Innovation and venture capital exits. The Economic Journal 118 (533), 1888-1916.

Shivdasani, A., Wang, Y., 2011. Did structured credit fuel the LBO boom? The Journal of Finance 56 (4), 1291-1328.

Sudarsanam, P., 2005. Exit Strategy for UK Leveraged Buyouts: Empirical Evidence on Determinants. Working paper, Cranfield School of Management.

Wang, Y., 2012. Secondary buyouts: Why buy and at what price? Journal of Corporate Finance 18 (5), 1306-1325. 